\title{
Uvajanje čuječnosti v študijski proces
}

\section{Janja Tekavc}

\section{Uvod}

$\mathrm{V}$

zadnjih desetletjih $\mathrm{v}$ zahodnem svetu beležimo porast zanimanja za koncept čuječnosti in izvajanje prakse čuječnosti. Čuječnost (angl. min$d$ fulness) pomeni usmerjanje lastne pozornosti na zavedanje trenutnega doživljanja oz. predstavlja proces »odprte, raziskujoče in zavedajoče se prisotnosti v trenutnem doživljanju « (Creswell, 2017: 493). Tovrstno jasno zavedanje $\mathrm{v}$ marsičem predstavlja nasprotje doživljanju sodobnega člove$\mathrm{ka}$, ki veliko dejavnosti počne $\mathrm{z}$ zmanjšano mero pozornosti in kateremu misli pogosto begajo iz ene stvari na drugo (npr. Bargh in Chartrand, 1999; Killingsworth in Gillbert, 2010). Čuječnost tako predstavlja proces usmerjanja lastne pozornosti na zavedanje trenutnega doživljanja, pri čemer posameznik zavzema držo radovednosti, odprtosti in sprejemanja (Bishop et. al., 2004). Čeprav pregled znanstvene literature pokaže na raznolikost v opredeljevanju pojma čuječnosti, vsebujejo vse njene opredelitve dve skupni značilnosti. To sta: (1) usmerjanje pozornosti in zavedanja na doživljanje sedanjega trenutka, ki lahko zavzema različne oblike, kot so telesne zaznave, čustvene reakcije, misli; ter (2) odprto sprejemanje oz. doživljanje notranjega in/ali zunanjega dogajanja na radoveden, nepristranski način.

Četudi je vsakdo zmožen čuječnosti, je lahko izvajanje tehnik čuječnosti na začetku precej zahtevno in terja nekaj napora. To je razumljivo, saj smo navajeni doživljanja na način, pri katerem našemu umu dopustimo, da 
prosto tava, pri čemer naše misli pogosto zaidejo v samokritiko, ruminacijo o preteklosti ali v skrbi glede prihodnosti (Creswell, 2017). Kadar posamezniku uspe vzpostaviti stanje čuječnosti (t.j. pozornost na sedanji trenutek, zavedanje, sprejemanje in ne-reagiranje), ima lahko to zanj zelo ugodne posledice. Raziskave o učinkovitosti izvajanja čuječnostnih praks namreč kažejo številne ugodne učinke na telesnem, kognitivnem, emocionalnem in vedenjskem nivoju (za pregled glej Creswell, 2017). Izvajanje čuječnostne vadbe namreč izboljša samoregulacijo psiholoških, vedenjskih in tudi telesnih reakcij posameznika (Hülsheger et al., 2015). Tako se pozitivne posledice na psihološkem nivoju kažejo predvsem kot povečana stopnja sproščenosti, istočasno pa tudi v izboljšanju nekaterih kognitivnih funkcij, kot so stopnja usmerjene pozornosti, učinkovitost delovnega spomina, večja jasnost in stopnja uvida v situacijo ter uspešnejše reševanje problemov (Eberth in Sedlmeier, 2012). Običajne čuječnostne prakse namreč ciljajo na več vidikov posameznikove pozornosti, kot so: prepoznavanje trenutka, ko začnejo misli uhajati, ponovno preusmerjanje pozornosti nazaj na fokus pozornosti (na primer na zavedanje procesa dihanja), razvijanje dolgotrajne pozornosti, in učenje zaznavanja na odprt način, pri katerem nas ne vodijo naše misli, čustva, ali telesna občutja. Redno izvajanje čuječnostne prakse naj bi pomagalo izboljšati tudi samoregulacijske spretnosti posameznika (Himelstein et. al., 2012). V sklopu čuječnostne prakse posameznik namreč opaža zunanje in notranje dogodke na odprt način in brez presojanja; ne da bi nanje reagiral. S pomočjo boljšega opažanja lastnega doživljanja in večjega meta-zavedanja je posameznik sposoben bolj objektivno oceniti zunanje in notranje dogodke, intenziteta njegovih čustvenih in vedenjskih reakcij pa se temu ustrezno zmanjša (Shapiro et. al., 2006). Redno izvajanje prakse čuječnosti vpliva tudi na socialno delovanje posameznika. Tako naj bi čuječnost pripomogla $\mathrm{k}$ izboljšanju posameznikovega medosebnega delovanja in dvignila kvaliteto njegovih odnosov z drugimi (npr. Carson .et al., 2004), zmanjšala občutke osamljenosti (Lindsay et al., 2019) in povečala količino prosocialnega vedenja posameznika (Condon et al., 2013). Raziskovalci omenjene učinke pripisujejo dejstvu, da redno izvajanje čuječnostne prakse pri posamezniku vzpostavljanja držo odprtega sprejemanja, poglobi uvid v posameznikovo stisko in $\mathrm{s}$ tem poveča stopnjo sočutja do drugih ljudi (Gunaratana, 2011).

Med programi, ki spodbujajo razvoj in poglabljanje čuječnosti, je zagotovo najbolj znan t.i. MBSR program (angl. Mindfulness-Based Stress Reduction program; Kabat-Zinn, 1982; 1990), ki predstavlja prvi strukturi- 
rani program za razvoj čuječnosti. Traja osem tednov in je sestavljen je iz rednih tedenskih skupinskih srečanj pod vodstvom učitelja, dnevne individualne vadbe ter enega daljšega dnevnega srečanja. Večina MBSR programa se osredotoča na učenje zavestnega usmerjanja pozornosti na telesne občutke s pomočjo različnih čuječnostnih tehnik. Izvajanje tehnik spremljajo pogovori in razlaga o tem, kako principe čuječnosti vključevati v vsakodnevno življenje, vključno s spoprijemanjem s stresom. Program MBSR je spodbudil razvoj tudi drugih podobnih programov, namenjenih razvijanju in poglabljanju čuječenosti, ki se med seboj razlikujejo v čuječnostnih tehnik, ki jih posamezni program vključuje, trajanju, izvedbi in ciljni skupini, kateri je program namenjen. $\mathrm{V}$ zadnjem desetletju beležimo porast krajših čuječnostnih intervencij v trajanju dveh do treh tednov, vse več pa je tudi čuječnostnih programov s pomočjo uporabe sodobnih tehnologij (računalnik, pametni telefon). Slednje so praktične za uporabo zaradi širše dostopnosti in nizkih stroškov izvedbe; njihova slaba stran pa je, da po navadi potekajo brez dostopa do učitelja (Creswell, 2017).

Zaradi številnih in raznolikih ugodnih učinkov, ki jih prinaša redno izvajanje čuječnostne prakse, sta koncept čuječnosti in spodbujanje razvoja čuječnosti vse bolj prisotna tudi v visokošolskem prostoru oz. v sklopu študijskega procesa. Skladno z raziskavami o psihološki obremenjenosti in stresu pri študentih (npr. Auerbach et al., 2018) se je razvilo tudi precejšnje število intervencij ter intervencijskih študij, katerih primarni namen je znižanje stopnje stresa pri študentih in izboljšanje njihovih sposobnosti spoprijemanja $\mathrm{z}$ njim. Mednje poleg oblik, kot so telesna vadba, vodenje dnevnika, glasbena terapija in meditacija, sodijo tudi različne čuječnostne prakse (Bamber in Schneider, 2016). Uporaba tehnik, ki spodbujajo čuječnost, lahko pomembno prispeva h kvalitetnejšemu študijskemu delu, saj spodbujajo proces spoznavanja, ustvarjalnost, refleksijo in vodijo h globljim uvidom v študijsko snov. Študent, ki k študiju pristopa na čuječ način, bo bolj pozoren na obravnavano snov in na lastna doživljanja $\mathrm{v}$ procesu učenja, posledično pa tudi veliko bolj zavzet za študij. Primerjava različnih tipov čuječnostnih intervencij na študentski populaciji je pokazala (Bamber in Morpeth, 2019), da se učinki večine programov, ki temeljijo na principu čuječnosti, med seboj pomembno ne razlikujejo glede učinkovitosti pri znižanju stopnje anksioznosti, depresije in stresa pri študentih. To pomeni, da so bili programi, ki so jih raziskovalci razvili za potrebe svojih študij, večinoma enako učinkoviti kot preverjene in dobro raziskane čuječnostne prakse, kot je npr. MBSR (angl. Mindfulness-Based Stress Reduction program; Ka- 
bat-Zinn, 1982; 1990). Programi za spodbujanje čuječnosti pri študentih naj bi bili bolj učinkoviti pri študentih nižjih letnikov kakor pri starejših študentih. Metaanalize intervencijskih študij, ki so kot intervencijo vključevale izvajanje čuječnostnih tehnik pri študentih, namreč kažejo, da tekom izvajanja tovrstnih programov stopnja anksioznosti pri študentih nižjih letnikov upade bolj kakor pri študentih višjih letnikov. Raziskovalci to pojasnjujejo z dejstvom, da študenti največ stresa in anksioznosti doživljajo v prvih letih svojega študija, zato imajo programi, ki ciljajo na znižanje stresa in bolj konstruktivno spoprijemanje z njim, največji učinek ravno pri tej skupini študentov (Bamber in Morpeth, 2019).

Prispevek opisuje rezultate uvajanja čuječnostne prakse v študijski program za študente 1 . stopnje psihologije. Namen raziskave je bil izvesti vodeni program razvijanja čuječnosti na daljavo in preveriti odzive študentov nanj. Pričakovali smo, da bodo študenti udeležbo v programu ocenili kot pozitivno izkušnjo in pri sebi prepoznali katero od sprememb na nivoju telesnega, psihološkega in socialnega delovanja, ki jih navajajo znanstveni viri na področju čuječnosti (npr. Creswell, 2017).

\section{Metoda}

V študiji smo uporabili 8 - tedenski program razvijanja čuječnosti, ki smo ga razvili na osnovi nekaterih objavljenih programov razvijanja čuječnosti pri študentih (npr. McClintock in Anderson, 2013; Zeidan et al., 2013). Program je bil sestavljen iz uvodnega predavanja, na katerem smo študente seznanili s pojmom čuječnosti, osnovnimi značilnostmi tehnik razvijanja čuječnosti ter principi izvajanja prakse čuječnosti in konkretnega programa. Sledilo je sedem različnih vaj za spodbujanje čuječnosti, ki so si sledile $\mathrm{v}$ tedenskem razmiku. Tako so študenti izvedli tehnike spodbujanja čuječnosti, kot so: čuječe dihanje, pregled telesa, čuječe gibanje, vodeno meditacijo $\mathrm{z}$ uporabo vizualizacije, postopno mišično relaksacijo, vodeno meditacijo ljubeče naklonjenosti in čuječe poslušanje zvokov. Na koncu je bilo izvedeno še zaključno srečanje, namenjeno refleksiji programa in evalvaciji. Program je v celoti potekal na daljavo (s pomočjo računalniškega sistema MS Teams). .

V program za razvijanje čuječnosti je bilo povabljenih 46 študentov študijskega programa psihologija. Udeležba v programu ni bila obvezna in ni sestavljala rednega dela študija. Prav tako sodelujoči študenti za sodelovanje v programu niso prejeli nobenih bonitet. Programa razvijanja čuječ- 
nosti se je tako udeležilo skupno 37 študentk $^{1}$ psihologije starih od 20 do 22 let. 23 udeleženk (oz. 62 \%) se je srečanj udeleževalo vedno ali skoraj vedno, vse udeleženke pa so bile prisotne na več kot polovici srečanj. Skoraj polovica udeleženk (47,8 \%) se je v sklopu izvedenega programa prvič srečala s konceptom čuječnosti, preostale so koncept čuječnosti poznali že prej. Enajst študentk (23,9 \%) je tehnike spodbujanja čuječnosti izvajalo že pred vključitvijo v omenjeni program, preostale so tovrstno prakso razvijanja čuječnosti izkusile prvič. Ob koncu izvedbe programa so udeleženke programa izpolnile anonimni spletni vprašalnik, s katerim so ocenile izvedeni program in odgovorile na nekatera druga vprašanja o njihovem pogledu na izvajanje programa čuječnosti v sklopu študijskega procesa. Uporabljeni vprašalnik je bil oblikovan za namene te študije; vključeval je štiri sklope postavk oz. trditev, ki so se nanašale na posamezničino doživljanje programa, opažene učinke izvajanja vaj, oceno programa in smiselnost uporabe čuječnosti v študijskem procesu. Postavke so temeljile na poročanih učinkih izvajanja tehnik čuječnosti, ki jih v svojih izsledkih največkrat omenjajo primerljive študije, opravljene na vzorcih študentov (npr. McClintock in Anderson, 2013; Zeidan et al., 2013). Prvotni nabor postavk je obsegal skupno 48 postavk. Po testni uporabi vprašalnika na treh udeležencih in podrobnem pregledu smo iz nabora izločili osem postavk, ki so se v vsebini podvajale; tri postavke, ki so se izkazale kot manj razumljive, pa smo jezikovno preoblikovali. Končni vprašalnik je tako obsegal 40 postavk. Rezultate smo analizirali s pomočjo opisne statistične analize.

\section{Rezultati}

Rezultati opisne statistične analize so pokazali, da so udeleženke svoje doživljanje izvajanja vaj za spodbujanje čuječnosti večinoma ocenjevale kot zelo pozitivno. Večina je poročala o prisotnih pozitivnih emocionalnih stanjih, kot so notranja motivacija za vključitev v izvajanje posamezne vaje, doživljanje pozitivnih čustev in sprostitve ob izvedbi. Podobno je relativno malo udeleženk zaznalo pri sebi neprijetna občutja, kot so dolgočasje ali iritacija. V tabeli 51 so prikazane srednje vrednosti $(M)$ in razpršitev $(S D)$ rezultatov po posameznih postavkah. Udeleženke so svoje strinjanje s posamezno trditvijo označile na petstopenjski ocenjevalni lestvici $(1=$ niko-

V študiji je sodelovalo 37 udeležencev, od tega 34 žensk in 3 moški. Zaradi izrazito prevladujočega ženskega spola v vzorcu se v nadaljevanju uporablja izraz »udeleženke« in »študentke«. 
li oz. zelo redko, $2=$ redko, $3=$ včasih, $4=$ pogosto in $5=$ zelo pogosto oz. vedno).

Tabela 51: Doživljanje izvajanja vaj za spodbujanje čuječnosti pri udeleženkah

\begin{tabular}{|c|c|c|}
\hline Postavka & M & $\mathrm{SD}$ \\
\hline Z veseljem sem se pridružil/a k izvajanju vaje. & 4,08 &, 92 \\
\hline Med izvajanjem vaje sem užival/a. & 4,03 &, 99 \\
\hline S pomočjo izvajanja vaj sem spoznal/a nekaj novega o sebi. & 3,41 & 1,01 \\
\hline Med izvajanjem vaj sem se dolgočasil/a. & 2,27 & 1,02 \\
\hline Med izvajanjem vaj sem doživel/a neprijetna občutja. & 1,78 &, 85 \\
\hline Težko sem sledil/a navodilom. & 2,24 & 1,07 \\
\hline Ob izvajanju vaj sem se sprostil/a. & 4,05 & ,99 \\
\hline Med izvajanjem vaj so mi misli zelo uhajale. & 3,32 &, 82 \\
\hline Med izvajanjem vaje sem bil/a prisoten/na in čuječa. & 3,32 &, 88 \\
\hline Med izvajanjem vaj me je veliko stvari motilo (npr. način izvedbe, glas, besedilo...) & 1,54 &, 73 \\
\hline Med izvajanjem vaje so me presenetili moji odzivi (npr. čustvene reakcije). & 2,54 &, 84 \\
\hline
\end{tabular}

Udeleženke študije so pri sebi opažale tudi nekatere spremembe, ki so vztrajale po izvedeni čuječnostni praksi, kot so višja stopnja sočutja do sebe in do drugih, višja čuječnost, nižja stopnja anksioznosti in boljše spoprijemanje s stresom. Tabela 52 prikazuje rezultate udeležencev o učinkih, ki so jih pri sebi opazile po izvedbi posamezne vaje in so jih pripisale učinkom izvajanja tehnike čuječnosti. Udeleženke so svoje strinjanje s posamezno trditvijo označile na petstopenjski ocenjevalni lestvici $(1=$ nikoli oz. zelo redko, $2=$ redko, $3=$ včasih, $4=$ pogosto in $5=$ zelo pogosto oz. vedno). Prikazane so srednje vrednosti $(\mathrm{M})$ in razpršitev $(\mathrm{SD})$ rezultatov po posameznih postavkah.

Tabela 52: Opažene spremembe pri udeleženkah po izvedbi čuječnostne vaje

\begin{tabular}{lcc}
\multicolumn{1}{c}{ Postavka } & M & SD \\
\hline Po izvedbi vaj sem čutil/a več energije. & 3,16 &, 96 \\
\hline Po izvedbi vaj sem imel/a več motivacije. & 3,40 &, 99 \\
\hline Po izvajanju vaj sem se lažje učil/a. & 3,21 &, 98 \\
\hline Po izvajanju vaj sem bil/a bolj prijazen/na in sočuten/na do sebe. & 3,75 &, 93 \\
\hline Po izvajanju vaj sem bil/a bolj prijazen/na in sočuten/na do drugih. & 3,68 & 1,03 \\
\hline Po izvajanju vaj sem bil/a bolj čuječ/a in pozoren/na na „tukaj in sedaj“. & 3,62 &, 95 \\
\hline Po vaji sem se tekom dneva še večkrat spomnil/a na občutja, ki sem jih doživel/a & 3,30 & 1,27 \\
med izvajanjem vaje. & 2,92 & 1,04 \\
\hline Zvečer sem lažje zaspal/a. & 3,40 &, 99 \\
\hline Po izvajanju vaje čuječnosti je bil moj dan lepši. & 3,19 & 1,13 \\
\hline Po izvajanju vaje čuječnosti sem bolje organiziral/a svoje dnevne aktivnosti. &
\end{tabular}


Udeleženke študije so ocenile tudi smiselnost uvajanja čuječnosti $v$ študijski proces in svojo motivacijo za vključitev v programe razvijanja čuječnosti, organizirane izven rednega študijskega procesa. Rezultati so prikazani v tabeli 53. Večina udeleženk je izrazila visoko stopnjo strinjanja $\mathrm{z}$ uvajanjem koncepta čuječnosti in tehnik za spodbujanje čuječnosti v visokošolski študijski proces ter menila, da bi slednje izboljšalo kvaliteto njihovega študija.

Tabela 53: Ocena smiselnosti vključevanja čuječnostne prakse v študijski proces

\begin{tabular}{lcc}
\multicolumn{1}{c}{ Postavka } & M & SD \\
\hline Tehnike izvajanja čuječnosti so dobrodošel del rednega študijskega programa. & 4,38 &, 76 \\
\hline $\begin{array}{l}\text { Menim, da bi lahko podobne vaje čuječnosti izvajali kot del rednega študijskega } \\
\text { procesa (npr. pred ali med predavanji). }\end{array}$ & 4,16 &, 93 \\
\hline $\begin{array}{l}\text { Če bi bil na fakulteti organiziran program učenja in izvajanja tehnik čuječnosti, bi } \\
\text { se ga z veseljem udeležil/a. }\end{array}$ & 3,84 & 1,17 \\
$\begin{array}{l}\text { Menim, da redno izvajanje tehnik čuječnosti pripomore k bolj učinkovitemu štu- } \\
\text { diju. }\end{array}$ & 4,00 &, 71 \\
\hline $\begin{array}{l}\text { Izvajanje tehnik čuječnosti med študijskim procesom (npr. pred ali med predava- } \\
\text { nji) bi povečalo mojo kvaliteto učenja. }\end{array}$ & 3,89
\end{tabular}

Udeleženke so ocenjevale tudi vpliv oz. korist, ki bi jo po njihovem mnenju prineslo izvajanje čuječnostne prakse med študijskim procesom na posamezne vidike njihovega študijskega dela in splošnega počutja (tabela 54). Korist izvajanja programa čuječnosti so ocenile s pomočjo petstopenjske ocenjevalne lestvice ( $1=$ povsem nekoristno, $2=$ pretežno nekoristno, 3 $=$ niti koristno, niti nekoristno, $4=$ pretežno koristno in $5=$ zelo koristno). Prikazane so srednje vrednosti (M) in razpršitev (SD) rezultatov po posameznih postavkah. Iz tabele lahko opazimo, da so udeleženke za večino od navedenih področij dela in delovanja ocenile, da bi lahko izvajanje prakse čuječnosti v sklopu študijskega procesa koristno vplivalo nanje. Še zlasti to velja za njihov odnos do samega sebe in do drugih, kvaliteto vsakdanjega življenja, spoprijemanje s stresom, pozornost in koncentracijo. 
Tabela 54: Ocena koristnosti vključevanja čuječnostne prakse v študijski proces na različnih področjih dela in delovanja

\begin{tabular}{|c|c|c|}
\hline Postavka & M & $\mathrm{SD}$ \\
\hline Splošno počutje in blagostanje & 3,95 & 1,00 \\
\hline Strokovno znanje & 3,62 & ,92 \\
\hline Vsakdanje življenje & 4,14 &, 67 \\
\hline Odnos s sabo & 4,30 &, 88 \\
\hline Odnos z drugimi & 4,14 &, 86 \\
\hline Samoregulacijske spretnosti (npr. organizacijo časa, osredotočenost na delo) & 3,78 &, 82 \\
\hline Pozornost in koncentracija & 4,11 &, 61 \\
\hline Spomin & 3,27 &, 90 \\
\hline Učinkovitost učenja & 3,73 &, 99 \\
\hline Kreativnost & 3,68 & 1,11 \\
\hline Samopodoba & 3,56 &, 90 \\
\hline Spoprijemanje s stresom & 4,14 &, 67 \\
\hline
\end{tabular}

Udeleženke smo povprašali tudi o tem, $\mathrm{v}$ kakšni obliki bi si želele $\mathrm{v}$ prihodnje izvajati podoben program razvijanja čuječnosti. Izvedbo v manjši skupini, organizirani izven rednega študijskega procesa, bi izbralo šest študentk ( $13 \%$ udeleženk), 32 študentk ( $87 \%$ ) bi tehnike spodbujanja čuječnosti umestilo v sklop rednega študijskega procesa, ena udeleženka (2 \%) pa se programa za razvijanje in spodbujanje čuječnosti ne bi želela udeležiti.

\section{Razprava}

S študijo, v kateri smo na zelo omejenem vzorcu študentske populacije izvedli 8-tedenski program spodbujanja čuječnosti na daljavo, smo želeli ugotoviti predvsem, kako študenti ocenjujejo tovrsten program izvajanja čuječnostne prakse ter kaj menijo o morebitni koristnosti njenega vključevanja v visokošolski študijski proces. Rezultati, pridobljeni ob koncu izvedenega programa so pokazali, da je večina udeleženk svojo izkušnjo sodelovanja pri izvajanju tehnik čuječnosti ocenila kot pozitivno in pri sebi opazila določene pozitivne učinke izvajanja čuječnostne prakse, zlasti na njihovem psihološkem nivoju delovanja, kot so višja stopnja čuječnosti, večje sprejemanje samega sebe in drugih, nižja stopnja anksioznosti in lažje spoprijemanje s stresom. Opisane spremembe se skladajo $\mathrm{z}$ rezultati predhodnih raziskav o ugodnih učinkih čuječnostne vadbe na psihološko stanje posameznika (npr. Himelstein et al., 2012; Khoury et al., 2015, Weinstein et al., 2009). Že kratka, na čuječnosti temelječa meditacija lahko pomembno zniža anksioznost in negativno razpoloženje posameznika ter zviša njegovo raven čuječnosti (McClintock in Anderson, 2013; Zeidan et al., 2013). Tudi 
raziskave o učinkovitosti izvajanja čuječnost praks pri študentih potrjujejo tovrstne ugodne učinke, saj med drugim kažejo, da sodelovanje v programih za spodbujanje in razvijanje čuječnosti pomaga izboljšati splošno blagostanje pri študentih in njihovo psihološko odpornost med študijskim letom, še zlasti pa v času izpitnih obdobij (npr. Galante et al., 2018). Nadalje naj bi izvajanje čuječnostne prakse pomembno znižalo stopnjo stresa in anksioznosti pri študentih, istočasno pa dvignilo njihovo stopnjo čuječnosti (Bamber in Schneider, 2016). Udeleženke v naši študiji so med koristmi izvajanja čuječnostne prakse prepoznavale tudi izboljšanje kognitivnih sposobnosti, kot so pozornost in koncentracija, učinkovitost učenja in spomin. To je lahko posledica večje sprostitve, ki so jo udeleženke pri sebi zaznavale med in po izvajanju čuječnostnih tehnik in potrjuje tezo, da stres in anksioznost pri študentih negativno vplivata na njihov spomin, koncentracijo in reševanje problemov (Beddoe in Murphy, 2004). Omenjeni rezultati pa so skladni tudi z izsledki avtorjev (npr. Bowlin in Baer, 2011), ki navajajo, da izvajanje vadbe čuječnosti ne pripomore samo k večji sprostitvi in zmanjšanju stresa, temveč tudi neposredno prispeva tudi k številnim ugodnim učinkom na področju njihovega kognitivnega delovanja (npr. na področju pozornosti, spomina in samoregulacije vedenja).

Večina udeleženk študije je pri sebi opazila porast v sprejemanju oz. meri sočutja do sebe in drugih ljudi. Obenem je večina ocenila, da utegne vključevanje čuječnostne prakse $\mathrm{v}$ študijski proces izboljšati njihov odnos s sabo in drugimi, kar potrjuje izsledke nekaterih raziskav (npr. Cohen in Miller, 2009), da lahko izvajanje programov za spodbujanje in razvijanje čuječnosti pri študentih vpliva tudi na razvoj njihovih socialnih kompetenc. To se zdi še posebej pomembno za študente študijskih programov, ki izobražujejo za poklice, kjer gre za veliko količino dela z ljudmi in t.i. čustvenega dela (Morris in Feldman, 1996).

Rezultati so pokazali tudi, da so bile udeleženke študije naklonjene ideji o vključevanju koncepta čuječnosti in čuječnostnih tehnik v visokošolski prostor. Programi za spodbujanje čuječnosti se jim zdijo smiselni in koristni tako za njihovo študijsko delo kot za vsakdanje življenje. Tudi primeri drugih podobnih študij (npr. Galante et al., 2018) kažejo, da je izvajanje študentom namenjenih programov razvijanja čuječnosti izvedljivo, za študente pa privlačno in učinkovito za krepitev njihovega psihofizičnega zdravja. To potrjuje mnenje raziskovalcev (npr. Bowlin in Baer, 2011), da predstavljajo programi za spodbujanje čuječnosti pri študentih poceni, učinkovito in večplastno rešitev za številne psihološke težave mladih odra- 
slih, obenem pa pripomorejo k dvigu njihovega splošnega blagostanja ter sposobnosti samoregulacije pozornosti, čustev in vedenja. Večina udeleženk naše študije bi se tako želela vključiti v program za razvijanje čuječnosti, organiziran v sklopu študijskega procesa, in meni, da lahko redno izvajanje tehnik čuječnosti pripomore $\mathrm{k}$ njihovemu bolj učinkovitemu študiju in izboljša kvaliteta njihovega učenja. Ker raziskave kažejo na to, da utegnejo biti tradicionalni čuječnostni programi (npr. MBSR program) za študente manj aktualni, saj zahtevajo od njih veliko časa in angažiranosti (Halladay et al., 2019), so za izvedbo primernejši krajši programi, ki so lahko tudi del rednega študijskega procesa. Temu pritrjujejo tudi rezultati naše študije, saj bi večina udeleženk tehnike spodbujanja čuječnosti najraje izvajala v sklopu rednega študijskega procesa.

\section{Pomanjkljivosti}

Pričujoča študija ima kar nekaj pomanjkljivosti, ki se navezujejo zlasti na njene metodološke omejitve in s tem ne dopuščajo izpeljave zaključkov, ki bi presegle opisni nivo rezultatov. Če bi želeli dejansko govoriti o učinkih izvajanja tovrstnega programa čuječnosti na omenjenem vzorcu, bi bilo potrebno rezultate primerjati s kontrolno skupino ali vsaj z začetnim stanjem, torej stanjem in počutjem posameznikov pred 8-tedenskim programom čuječnosti. Precejšnja omejitev obravnavane študije je tudi omejen vzorec udeležencev, $v$ katerega so bili vključeni študenti zgolj ene študijske smeri, v pretežni meri pa so prevladovale ženske. Za posplošitev rezultatov na celotno populacijo študentov bi bilo potrebno poskrbeti za bolj reprezentativen vzorec, ki bi enakovredno zajel oba spola in študente različnih študijskih smeri ter starosti. Kljub precejšnjim omejitvam pa prispevek ponuja dober temelj za vpeljavo tovrstnih praks $\mathrm{v}$ študijski prostor in raziskovanje njegovih učinkov uporabe čuječnosti v prihodnje. Še posebej tako priporočamo izvedbo intervencijskih študij s kontrolno skupino udeležencev in razširitev nabora instrumentarija $\mathrm{z}$ uporabo standardiziranih psiholoških instrumentov.

\section{Sklepi}

Spodbujanje in poglabljanje čuječnosti ima lahko za študente številne ugodne učinke, kot so izboljšano duševno zdravje in splošno blagostanje, razvoj empatije, povečano sprejemanje sebe in drugih ter izboljšano kognitivno delovanje. Spodbujanje čuječnosti v okviru visokošolskega izobraževanja 
lahko pomembno prispeva $\mathrm{k}$ bolj kvalitetnemu učnemu procesu študentov. Rezultati obravnavane študije so pokazali, da so študenti naklonjeni vključevanju programov za spodbujanje čuječnosti v visokošolski prostor, saj prepoznavajo številne koristi izvajanja čuječnostnih praks. Na podlagi tega se zdijo smiselne pobude o vključevanju principov čuječnosti in izvajanja čuječnostnih praks v visokošolsko izobraževanje.

\section{Literatura}

Bamber, Mandy D. in Erin Morpeth. „Effects of mindfulness meditation on college student anxiety: A meta-analysis.“ Mindfulness 10.2 (2019): 203214.Bargh, John A. in Tanya L. Chartrand. „The Unbearable Automaticity of Being,“ American Psychologist 54 (1999): 462-479.

Beddoe, Amy E. in Susan O. Murphy. „Does mindfulness decrease stress and foster empathy among nursing students?“" Journal of Nursing Education 43.7 (2004): 305-312.

Bishop, Scott R., et al. „Mindfulness: a proposed operational definition.“ Clinical psychology: Science and practice 11.3 (2004): 230.

Bowlin, Stephanie L. in Ruth A. Baer. „Relationships between mindfulness, self-control, and psychological functioning." Personality and Individual Differences 52.3 (2012): 411-415.

Canby, Nicholas K., et al. „A brief mindfulness intervention for healthy college students and its effects on psychological distress, self-control, meta-mood, and subjective vitality." Mindfulness 6.5 (2015): 1071-1081.

Carson, James W., et al. „Mindfulness-based relationship enhancement.“ Behavior Therapy 35 (2004): 471-494.

Cohen, Jeanette, and Lisa Miller. „Interpersonal mindfulness training for well-being: A pilot study with psychology graduate students.“ Teachers College Record 111.12 (2009): 2760-2774.

Condon, Paul, et al. „Meditation increases compassionate responses to suffering." Psychological science 24.10 (2013): 2125-2127.

Creswell, J. David. „Mindfulness interventions.“ Annual review of psychology 68 (2017): 491-516.

Eberth, Juliane, and Peter Sedlmeier. „The effects of mindfulness meditation: a meta-analysis." Mindfulness 3.3 (2012): 174-189.

Galante, Julieta, et al. „A mindfulness-based intervention to increase resilience to stress in university students (the Mindful Student Study): a pragmatic randomised controlled trial." The Lancet Public Health 3.2 (2018): 72- 
81.Gunaratana, Bhante Henepola, Mindfulness in plain English (Boston. MA: Wisdom, 2011).

Halladay, Jillian E., et al. „Mindfulness for the mental health and well-being of post-secondary students: A systematic review and meta-analysis.“ Mindfulness 10.3 (2019): 397-414.

Himelstein, Sam, et al. „Mindfulness training for self-regulation and stress with incarcerated youth: A pilot study. " Probation Journal 59.2 (2012): 151165.

Hülsheger, Ute R., Alina Feinholdt in Annika Nübold. „A low-dose mindfulness intervention and recovery from work: Effects on psychological detachment, sleep quality, and sleep duration." Journal of occupational and organizational psychology 88.3 (2015): 464-489.

Kabat-Zinn, Jon. „An outpatient program in behavioral medicine for chronic pain patients based on the practice of mindfulness meditation: Theoretical considerations and preliminary results." General hospital psychiatry 4.1 (1982): 33-47.

Kabat-Zinn,Jon. Full Catastrophe Living: Using the Wisdom of Your Body and Mind to Face Stress, Pain, and Illness (New York: Delta, 1990).

Khoury, Bassam, et al. „Mindfulness-based stress reduction for healthy individuals: A meta-analysis.“ Journal of psychosomatic research 78.6 (2015): 519-528.

Killingsworth, Matthew A. in Daniel T. Gilbert. „A wandering mind is an unhappy mind." Science 330.6006 (2010): 932-932.

Lindsay, Emily K., et al. „Mindfulness training reduces loneliness and increases social contact in a randomized controlled trial." Proceedings of the National Academy of Sciences 116.9 (2019): 3488-3493.

McClintock, Andrew S., and Timothy Anderson. „The application of mindfulness for interpersonal dependency: Effects of a brief intervention." Mindfulness 6.2 (2015): 243-252.

Morris, J. Andrew in Daniel C. Feldman. „The dimensions, antecedents, and consequences of emotional labor." Academy of management review 21.4 (1996): 986-1010.

Shapiro, Shauna L., et al. „Mechanisms of mindfulness.“ Journal of clinical psychology 62.3 (2006): 373-386.

Zeidan, Fadel, et al. „Effects of brief and sham mindfulness meditation on mood and cardiovascular variables." The Journal of Alternative and Complementary Medicine 16.8 (2010): 867-873.

Weinstein, Netta, Kirk W. Brown, and Richard M. Ryan. „A multi-method examination of the effects of mindfulness on stress attribution, coping, and emotional well-being." Journal of research in personality 43.3 (2009): $374-385$. 